\title{
Factor Analysis and Comprehensive Evaluation of Operation Effect of Electric Heating Systems
}

\author{
Li ZHOU* \\ North China Electric Power University, No.2, Beinong \\ Road, Huilongguan, Changping District, Beijing, China, \\ 102206 \\ e-mail: 18262308265@163.com
}

\author{
Yongli WANG \\ North China Electric Power University, No.2, Beinong \\ Road, Huilongguan, Changping District, Beijing, China, \\ 102206
}

\begin{abstract}
Arising with economy growth is the awareness of protecting the environment, public has paid more and more attention to Electric Heating in recent years. However, currently Electric Heating in China cannot reach the optimal operation due to several constraints, which hinders Electric Heating's popularization. Our paper analyzed factors impacting their operation effect including economy, safety and environment protection. Then we extracted metrics and develop a comprehensive evaluation system for Electric Heating operation, based on the Multi-level Grey Correlation Analysis Method. We aimed to study how to realize Electric Heating's operation optimization. In the end, we assessed all kinds of Electric Heating and make constructive designs for Electric Heating promotion in China.
\end{abstract}

Keywords-Electric Heating, Factor Analysis, Multi-level Grey Correction Analysis Method; Comprehensive Evaluation

\section{INTRODUCTION}

In 2013, State Grid of China formally put forward Electric Power Substitution Strategy, reckoning encouraging residents to use electric heating as an essential task. In China, there are mainly two traditional heating systems: Cogeneration and Coal-fire Heating System. Coal burning and low heating effectiveness result in serious air-pollution. Gradually, Electric Heating is replacing traditional heating systems and is expected to be the protagonist in the near further.

There are many researches concentrating on economic and environmental effects of Electric Heating System. Paper [1] compares Electric Heating to Gas Heating, does quantitative analysis regard of initial investment and running cost. Paper [2] assesses environmental effects of different heating systems through measuring emission factors of pollution, and concludes which is the most environmental-friendly heating system.

There are few papers about Electric Heating's safety both in China and abroad. Reference to GB 5226-2008, and according to my own living experience, I conclude factors and metrics of Electric Heating's safety.
Paper [3] and Paper [4] respectively provide us with solid scientific basis about residential buildings' heating system and a set of comprehensive evaluation system, which assist us to assess operation effects of Electric Heating System smoothly.

\section{ANALYSIS OF FACTORS INFLUENCING ELECTRIC HEATING'S OPERATION}

When choosing Electric Heating System, investors are usually concerned about good economic benefits, while users care about which one is the most energy-efficient, with comfort experience and better safety. And governments tend to consider resource consumption reduction and pollutant emissions, in regard to obvious environmental and social benefits.

In this section, we synthesize the focuses of investors, users and governments, and pick relative factors and metrics in economy, safety, and environment protection, which are shown in Table 1.

\section{COMPREHENSIVE EVAlUATION BASED ON THE MULTI-LEVEL GREY CORRELATION ANALYSIS METHOD[3][4]}

In section, we extract six metrics from the three factors mentioned above, which can represent each factor perfectly. With the help of AHP and Entropy Method, we determine weights of each metrics. Then do assessment calculation of different types of Electric Heating with the Multi-level Grey Relational Analysis Method.

\section{A Metric Extraction}

In order for accuracy and rationality of evaluation, metrics option and filtering should obey these principles: systematic, scientific, operable, and independent.

According to the former passage, we extract 9 metrics--three belong to economy, three belong to safety, and three belong to environment. Shown in Figure 1, they are: annual cost, payback period, profit rate, aging degree of heater, incident rate, safety level of heater, electric consumption, primary resource utility efficiency and temperature raising speed. 
TABLE I. FACTORS INFLUENCING THE OPERATION EFFECT OF ELECTRIC HEATING

\begin{tabular}{|c|c|c|}
\hline First Level & Second Level & \multirow{2}{*}{ 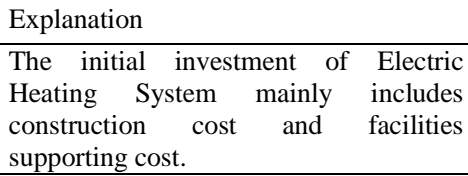 } \\
\hline \multirow{2}{*}{ (1) Economy } & (1)Initial investment & \\
\hline & (2)Operation cost & $\begin{array}{l}\text { The operating costs of centralized } \\
\text { heating consist of fuel cost, water and } \\
\text { electricity charges, and management } \\
\text { cost. }\end{array}$ \\
\hline \multirow{2}{*}{ (2) Safety and Reliability } & (1)GB5226.1-2008 & $\begin{array}{l}\text { Power Switch, Protection against } \\
\text { Electric Shock, Electrical Equipment } \\
\text { Protection and Control Circuit and } \\
\text { Control Function. }\end{array}$ \\
\hline & $\begin{array}{l}\text { (2)Equipment's continuously-used } \\
\text { time }\end{array}$ & Degree of aging. \\
\hline \multirow{6}{*}{ (3) Environment Protection } & (1)Pollution emissions & $\mathrm{SO}_{2}, \mathrm{NO}_{\mathrm{x}}, \mathrm{CO}_{2}$, and Solid particles. \\
\hline & \multirow{5}{*}{$\begin{array}{l}\text { (2)Energy Conservation } \\
\bullet \quad \text { Technical efficiency } \\
\text { - Temperature Difference }\end{array}$} & $\begin{array}{l}\text { a) Centralized or decentralized } \\
\text { Heating }\end{array}$ \\
\hline & & b) Director or regenerative heating \\
\hline & & c) Temperature control \\
\hline & & d) Natural Climate \\
\hline & & $\begin{array}{l}\text { e) Thermal Insulation performance of } \\
\text { Buildings }\end{array}$ \\
\hline
\end{tabular}

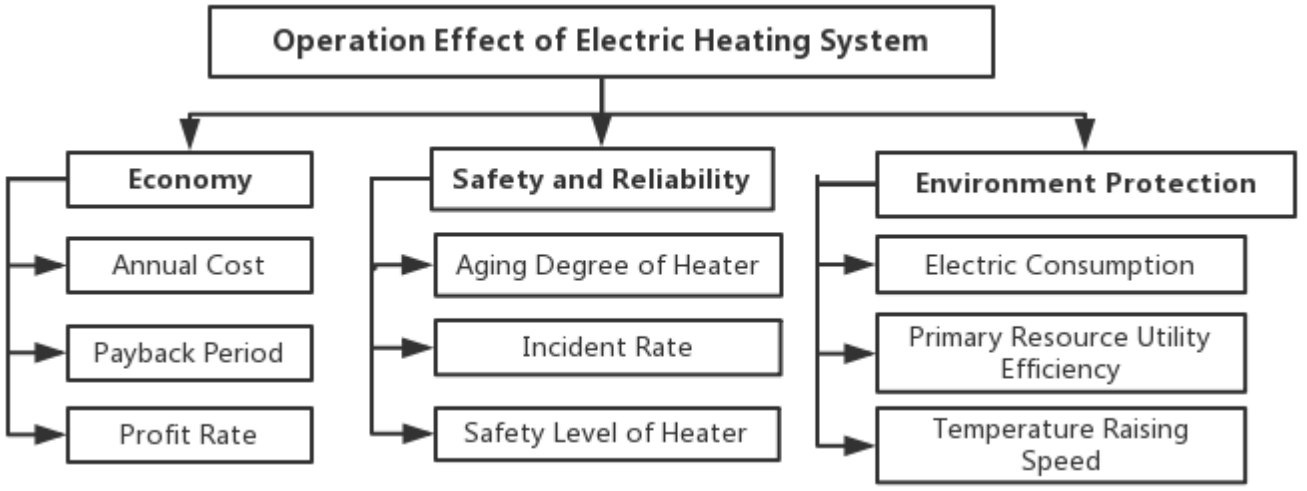

Figure 1. Metrics to describe operation effects of Electric Heating System

\section{B Weight Determination}

In this section, we combine qualitative analysis with quantitative calculation, eventually get combined weights' value. This first method of weight determination is AHP based on Delphi, which is subjective. And then we use Entropy Method to correct weights getting through AHP. In the end, we make a combination of weights getting through the two methods to keep objective.

\section{Subjective Weights}

We distributed 20 questionnaires to professors, heating users and Electric Heater sellers, asking them some relevant questions about Electric Heating. In the end, we recover the 20 questionnaires, and do statistics about the answers. With the method of AHP, we compare the importance between metrics. Then we get the important weights of layer B to layer A, and weights of layer $\mathrm{C}$ to layer $\mathrm{B}$. All the important weights contribute to an original judging matrix. Based on the matrix, we get the subjective weights of all the metrics:

$$
\begin{gathered}
\omega_{A}=\{0.3039,0.4509,0.2452\} \\
\omega_{A H P-B 1}=\{0.1692,0.3873,0.4435\} \\
\omega_{A H P-B 2}=\{0.1129,0.5050,0.3820\} \\
\omega_{A H P-B 3}=\{0.4435,0.1692,0.3873\}
\end{gathered}
$$

\section{$D \quad$ Correction of Subjective Weights}

With the method of Entropy, we correct the subjective weights got from AHP:

$$
\begin{aligned}
& \mathrm{h}_{B 1}=\{0.3246,0.3365,0.3390\} \\
& \mathrm{h}_{B 2}=\{0.3315,0.3341,0.3344\} \\
& \mathrm{h}_{B 3}=\{0.3015,0.3734,0.3251\}
\end{aligned}
$$


E Weight Combination

Use the formula to combine weights:

$$
\mathrm{W}=\frac{\mathrm{w}_{\mathrm{AHP}_{\mathrm{j}} \mathrm{h}_{\mathrm{j}}}}{\sum_{\mathrm{j}=1}^{\mathrm{n}} \mathrm{w}_{\mathrm{AHP} \mathrm{j}_{\mathrm{j}} \mathrm{h}_{\mathrm{j}}}}, \mathrm{j}=1,2, \ldots \ldots, \mathrm{n}(1)
$$

Where $\mathrm{w}_{\mathrm{AHP} \mathrm{j}}$ is the subjective weight calculated by AHP, $h_{j}$ is the weight calculated by Entropy. Finally, we get weights of metrics under three factors:

$$
\begin{aligned}
& \omega_{B 1}=\{0.1637,0.3883,0.4480\} \\
& \omega_{B 2}=\{0.1121,0.5053,0.3825\} \\
& \omega_{B 3}=\{0.4143,0.1957,0.3900\}
\end{aligned}
$$

\section{CAlCulation}

Electric Heating is a complex system There are many metrics we can use to depict heating operation effects. The actual statistic collection is inevitably of a certain degree of gray. One of the Grey Relational Analysis Method's advantage is processing evaluation objection when it information is not entirely clear. It has high accuracy for assessing irregular small sample. So it is suitable to apply the Grey Relational Analysis Method to evaluate Electric Heating System. On top of that, with regard to multi-level comprehensive evaluation embraces more information than the single-level one. Our paper will introduce Multi-level gray relational analysis into the evaluation of Electric Heating. We grade the following objections in 9-Grade Score and all the metrics are positive. The result is given in Table 2:

TABLE II. SCORES

\begin{tabular}{|l|l|l|l|l|l|l|l|}
\hline Scores & $\begin{array}{l}\text { Ordinary } \\
\text { electric } \\
\text { boiler }\end{array}$ & $\begin{array}{l}\text { Regenerative } \\
\text { electric } \\
\text { boiler }\end{array}$ & $\begin{array}{l}\text { Heat } \\
\text { Pump }\end{array}$ & $\begin{array}{l}\text { Direct } \\
\text { Heater }\end{array}$ & $\begin{array}{l}\text { Regenerative } \\
\text { DirectHeater }\end{array}$ & $\begin{array}{l}\text { Electric } \\
\text { Heating } \\
\text { Film }\end{array}$ & $\begin{array}{l}\text { Electric } \\
\text { Heating } \\
\text { Floor }\end{array}$ \\
\hline Annual Cost & 2 & 4 & 9 & 6 & 7 & 3 & 1 \\
\hline $\begin{array}{l}\text { Payback } \\
\text { Period }\end{array}$ & 2 & 4 & 9 & 7 & 8 & 3 & 1 \\
\hline Profit Rate, & 3 & 2 & 7 & 9 & 8 & 3 & 3 \\
\hline $\begin{array}{l}\text { Aging } \\
\text { Degree }\end{array}$ & 9 & 9 & 9 & 9 & 9 & 9 & 9 \\
\hline Incident Rate & 5 & 5 & 9 & 5 & 5 & 9 & 9 \\
\hline Safety Level & 9 & 9 & 9 & 7 & 7 & 9 & 9 \\
\hline $\begin{array}{l}\text { Electric } \\
\text { Consumption }\end{array}$ & 1 & 1 & 8 & 9 & 9 & 5 & 5 \\
\hline $\begin{array}{l}\text { Primary } \\
\text { Resource } \\
\begin{array}{l}\text { Utility } \\
\text { Efficiency }\end{array}\end{array}$ & 5 & 5 & 9 & 3 & 4 & 3 & 3 \\
\hline $\begin{array}{l}\text { Temperature } \\
\text { Raising } \\
\text { Speed }\end{array}$ & 9 & 9 & 9 & 6 & 6 & 5 & 5 \\
\hline
\end{tabular}

(Provided that all forms of electric heating are new, their aging degree is 0 )

An ideal optimal solution is $\mathrm{x}^{*}=(9,9,9)$.

Correlation coefficient can be calculated like this:

$\xi_{\mathrm{i}}(\mathrm{k})=\frac{\Delta \min +\rho \Delta \max }{\Delta_{\mathrm{i}}(\mathrm{k})+\rho \Delta \max }, \mathrm{i}=1,2, \ldots \ldots, \mathrm{n} ; \mathrm{k}=1,2, \ldots \ldots, \mathrm{m}$
We can get the correlation coefficient Matrix shown in Table 3:

\section{A Evaluation of the First-Grade Metrics}

The first metric is Economy, weights of its metrics are:

$$
\omega_{B 1}=\{0.1637,0.3883,0.4480\}
$$

TABLE III. CORRELATION COEFFICIENT MATRIX

\begin{tabular}{|l|l|l|l|l|l|l|l|}
\hline & 1 & 2 & 3 & 4 & 5 & 6 & 7 \\
\hline 1 & 0.6667 & 0.5000 & 0.3077 & 0.4000 & 0.3636 & 0.5714 & 0.8000 \\
\hline 2 & 0.6667 & 0.5000 & 0.3077 & 0.3636 & 0.3333 & 0.5714 & 0.8000 \\
\hline 3 & 0.5714 & 0.6667 & 0.3636 & 0.3077 & 0.3333 & 0.5714 & 0.5714 \\
\hline 4 & 0.3077 & 0.3077 & 0.3077 & 0.3077 & 0.3077 & 0.3077 & 0.3077 \\
\hline 5 & 0.4444 & 0.4444 & 0.3077 & 0.4444 & 0.4444 & 0.3077 & 0.3077 \\
\hline 6 & 0.3077 & 0.3077 & 0.3077 & 0.3636 & 0.3636 & 0.3077 & 0.3077 \\
\hline 7 & 0.8000 & 0.8000 & 0.3333 & 0.3077 & 0.3077 & 0.4444 & 0.4444 \\
\hline 8 & 0.4444 & 0.4444 & 0.3077 & 0.5714 & 0.5000 & 0.5714 & 0.5714 \\
\hline 9 & 0.3077 & 0.3077 & 0.3077 & 0.4000 & 0.4000 & 0.4444 & 0.4444 \\
\hline
\end{tabular}

Through the correlation degree calculation, we get first evaluation about Economy: $\gamma_{1}=\mathrm{w}_{1} \xi_{1}=[0.3799,0.4082,0.8507,0.8004,0.7782$, $0.4000,0.3632]$ 
From this result, we are informed that Heat pump heating, direct heating, and regenerative direct heating are better than other electric heating forms in Economy.

Similarly, we follow steps above and do calculation for the second and third factors:

The second metric is Safety and Reliability: $\omega_{\mathrm{B} 2}=\{0.1122,0.5053,0.3825\}$

$\gamma_{2}=[0.6889,0.6889,0.9234,0.7754,0.7754,0.8087$, $0.8087]$

From this result, we are informed that Heat pump heating, electric heating film and electric heating floor are better than other electric heating forms in Safety and Reliability.

The third metric is Environment Protection: $\omega_{\mathrm{B} 3}=\{0.4143,0.1957,0.3900\}$

$\gamma_{3}=[0.5945,0.5945,0.5945,0.4170,0.4170,0.3874$, $0.3874]$

From this result, we are informed that ordinary electric boiler, regenerative electric boiler, heat pump heating is all better than other electric heating forms in Environment Protection.

$B$ Evaluation of the Second-Grade Factors

Importance weights of the three factors are: $\omega_{\mathrm{A}}=\{0.3039,0.4509,0.2452\}$

The total correlation degree is:

$\gamma=\omega_{\mathrm{A}}\left[\gamma_{1}, \gamma_{2}, \gamma_{3}\right]=[0.5718,0.5804,0.8207,0.6851$, $0.6984,0.5812,0.5700]$

Rank objections by correlation degrees:

Heat pump $>$ Regenerative direct heating $>$ Directelectric Heating $>$ Electric heating film $>$ Regenerative electric boiler $>$ Ordinary electric boiler $>$ Electric Heating Floor

In conclusion, Electric Boiler brings about better environment effects than other forms, but it has little economic benefits. Centralized Electric Heating has better environmental effect, but worse economic effect; Decentralized Electric Heating has better safety and reliability, but worse economic effect and environmental effect. As a form of centralized Electric Heating, Heat pump has absolute advantages over someone else, for it perform well in economy, safety and environment protection.

\section{V.CONCLUSIONS}

From a perspective of comprehensive benefits, heat pump should be preferred if meeting its installation conditions.

\section{A There Some Areas Uncovered in Existing Urban Central Heating Pipe Networks}

1. New buildings: The rapid urban development leads to a large number of new residential buildings and public constructions being completed every year. But heating demand can't be met timely due to construction of centralized heating system and a pipe network is slow.

2. Old communities and administrative building transformation: Old residential and administrative buildings have been constructed for many years that supported by traditional coal-fired boiler heating.

3. Distributed heating users: Remote suburbs around one urban, villages in a city, and other areas where municipal infrastructure facilities are not sufficient, areas uncovered in heating pipe networks and in the south of China where there is no centralized heating.

\section{B Electric Heating Promotion Designs [5]}

Our paper convinces that electric boilers are suitable to replace the coal-fired heating in old communities and administrative building. The original boiler rooms can be transformed to electric boiler rooms; the original heap yard in open air can be transformed to green land. We prefer regenerative electric boilers to ordinary ones, because regenerative electric boilers reduce operation cost, as well as adding economic benefits for power generation enterprises. Under such conditions, power enterprises are willing to give users some price concessions, encouraging them to use Electric Heating.

Ground source heat pump system can not only be used for winter heating, but also for summer cooling, but also for living hot water supply. It can be used for winter heating in hotels, shopping malls, office buildings and new large residential areas. Heat Pump is now the most efficient form of Electric Heating. Objections' investigation has been identified with a shallow geothermal area can be used to install the source heat pump heating system.

As two decentralized electric heaters, Electric Heating Film and Electric Heating Floor are mainly used in independent residential buildings, especially high-end residential villas. Radiant Electric Heating's initial investment and operating costs is higher. But their energy-saving benefit and cost reduction are considerable. There is a promotion program of Electric Heating in Table 4:

TABLE IV. PROMOTION PROGRAM

\begin{tabular}{|l|l|l|l|}
\hline Objections & $\begin{array}{l}\text { New } \\
\text { buildings }\end{array}$ & $\begin{array}{l}\text { Old } \\
\text { Communities }\end{array}$ & $\begin{array}{l}\text { Distributed } \\
\text { heating users }\end{array}$ \\
\hline Options & $\begin{array}{l}\text { Heat } \\
\text { Pump }\end{array}$ & $\begin{array}{l}\text { Electric } \\
\text { Boiler } \\
\text { Heating }\end{array}$ & $\begin{array}{l}\text { Electric Heating } \\
\text { Film or Electric } \\
\text { Heating Floor }\end{array}$ \\
\hline
\end{tabular}

\section{REFERENCES}

[1] LIU Yang, RAN Chunyu, 2016, Journal of Chifeng University (Natural Science Edition), (In Chinese)

[2] XU Gang, WANG Chunlan, XU Cheng, BAI Pu, 2016, Research of Environmental Sciences. (In Chinese)

[3] XIAO Xiao, LI Deying, LIU Shan, 2011, Building and Energy Conservation. (In Chinese)

[4] LUO Yi, ZHOU Chuangli, LIU Xiangjie, 2012, Proceedings of the CSEE. (In Chinese)

[5] CHEN Haoli, Research on Scheme Selection and Benefit Analysis of Electric Heating in KuiTun City [D], North Power China Electric Power University, 2015. (In Chinese)

[6] ZHANG Jingbo, WU Jianbing, SHOU Weiwei, 2011, Heating, Ventilation and Air Conditioning. (In Chinese)

[7] WANG Bojun, 2002, Gas and Heat. (In Chinese) 